\title{
Co-trimoxazole in prevention of bacteriuria after prostatectomy
}

\author{
N H HILLS, M I BULTITUDE, SUSANNAH EYKYN
}

British Medical fournal, 1976, 2, 498-499

\begin{abstract}
Summary
In a prospective, double-blind trial prophylactic cotrimoxazole produced a highly significant reduction in the incidence of bacteriuria after prostatectomy. Only two out of 38 patients who received the drug developed bacteriuria compared with 19 out of 36 patients on placebo. Klebsiella-Enterobacter spp and coagulasenegative staphylococci were responsible for most infections. Although co-trimoxazole prophylaxis is obviously effective, widespread use might increase the incidence of bacterial resistance.
\end{abstract}

\section{Introduction}

The use of prophylactic antibiotics in urological surgery has been much debated recently. The results of clinical trials have conflicted, and so it has been difficult to establish a rationally based clinical regimen. Data collected in St Thomas's Hospital showed that the incidence of bacteriuria after prostatectomy was unacceptably high but that patients who received preoperative prophylactic antibiotics (usually given for a coexisting respiratory infection) developed bacteriuria less often than those who received no antibiotics. We decided to subject this impression to a rigorous clinical trial.

\section{Patients and methods}

A prospective double-blind controlled trial was devised to investigate the effects of preoperative prophylactic co-trimoxazole on the incidence of bacteriuria after prostatectomy. Co-trimoxazole was selected because of its activity against most urinary pathogens and its attainment of high blood and urine concentrations. The long half life of the drug allowed oral administration some four to six hours before surgery.

All patients in the urological ward undergoing prostatectomy were accepted for the trial except those whose urine was already infected, those already receiving antibiotics, and those hypersensitive to cotrimoxazole or sulphonamide. Each patient included in the trial received either co-trimoxazole or placebo tablets (containing lactose, starch maize, avicel, gelatin, and magnesium stearate) according to a predetermined randomised order, known to neither investigators nor patients. Medication was started on the morning of the day of operation and continued for 10 days or until the patient left hospital, whichever was the shorter period. The dose was two tablets every 12 hours.

Urine specimens (midstream specimens or, in the presence of a catheter, aspirations from the catheter tubing) were taken before prophylaxis was started, at operation, and on alternate days for 10 days. Bacteriuria was diagnosed when $10^{5}$ organisms per $\mathrm{ml}$ of urine were grown on culture from any one of these specimens. The technique of prostatectomy was standardised, but the operations were performed by different surgeons. After retropubic operations a $22 \mathrm{~F}$ Kinder urethral catheter (retained by a stitch and a Harris Bar) was used for bladder drainage to a closed collecting system. After transurethral operations a single lumen $22 \mathrm{~F}$ plastic balloon type catheter was used. Intermittent irrigation with sterile physiological saline was performed until bleeding stopped. No local antibacterial agents were used.

Departments of Urology and Microbiology, St Thomas's Hospital, London SE1 7EH

N H HILLS, MB, FRCS, senior registrar in urology

$M$ I BULTITUDE, MB, FRCS, senior registrar in Urology

SUSANNAH EYKYN, MB, MRCPath, senior lecturer in clinical microbiology
In most patients urethral swabs were taken for culture both before operation and daily thereafter until the catheter was removed using the method previously described by Bultitude and Eykyn. ${ }^{1}$

\section{Results}

Eighty patients entered the trial, but six were later excluded because of failure to comply with the protocol of the trial, so 74 patients remained for analysis. The mean $( \pm S D)$ age of the patients in the placebo group was $67 \cdot 3 \pm 7 \cdot 2$ years and in the co-trimoxazole group $67 \cdot 7 \pm 7 \cdot 9$ years. The closeness of these figures indicates that satisfactory randomisation was achieved.

Nineteen $\left(53^{\circ}\right)$ of the 36 patients who received placebo and two $\left(5^{\circ}{ }_{0}\right)$ of the 38 who received co-trimoxazole developed bacteriuria $\left(\gamma^{2}=14.30 ; P<0.001\right)$. In table $I$ this incidence is analysed according to the type of prostatectomy. The organisms isolated from the urine in the 21 patients who developed bacteriuria are shown in table II. All organisms isolated were sensitive to co-trimoxazole on disc testing.

Urethral swabs were cultured from 57 of the 74 patients $(24$ on placebo, 33 on co-trimoxazole). The urethra was already colonised with bacteria at the start of the trial in 51 of the 57 patients. In 27 patients more than one organism was grown. Coagulase-negative staphylococci were most frequently isolated and were found in $71^{\circ}$ o of patients. Urethral colonisation persisted throughout the period of catheterisation in 22 of the 24 patients in the placebo group and in 28 of the 33 patients in the co-trimoxazole group. The organisms isolated are shown in table III. There was no difference in the genera of bacteria cultured from the co-trimoxazole and placebo groups. Urethral cultures were studied in nine of the patients who developed bacteriuria (all in the placebo group); in every case the organism cul-

TABLE I-Incidence of bacteriuria according to type of prostatectomy

\begin{tabular}{|c|c|c|c|c|}
\hline & & & \multirow[b]{2}{*}{$\begin{array}{l}\text { No with } \\
\text { sterile urine }\end{array}$} \\
\hline & & $\begin{array}{c}\text { No of } \\
\text { patients }\end{array}$ & $\begin{array}{c}\text { No developing } \\
\text { bacteriuria }\end{array}$ & \\
\hline \multicolumn{5}{|c|}{ Retropubic operations } \\
\hline $\begin{array}{l}\text { Placebo.. } \\
\text { Co-trimoxazole }\end{array}$ & . & $\begin{array}{l}19 \\
21\end{array}$ & $\begin{array}{r}13\left(688^{\prime \prime}{ }_{0}\right) \\
2\left(9 \cdot 5{ }^{\circ}{ }_{0}\right)\end{array}$ & $\begin{array}{r}6 \\
19\end{array}$ \\
\hline \multicolumn{5}{|c|}{ Transurethral operations } \\
\hline $\begin{array}{l}\text { Placebo... } \\
\text { Co-trimoxazole }\end{array}$ & 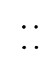 & $\begin{array}{l}17 \\
17\end{array}$ & $\begin{array}{l}6(35 \%) \\
\quad 0\end{array}$ & $\begin{array}{l}11 \\
17\end{array}$ \\
\hline
\end{tabular}

TABLE II-Organisms isolated from urine of patients who developed bacteriuri

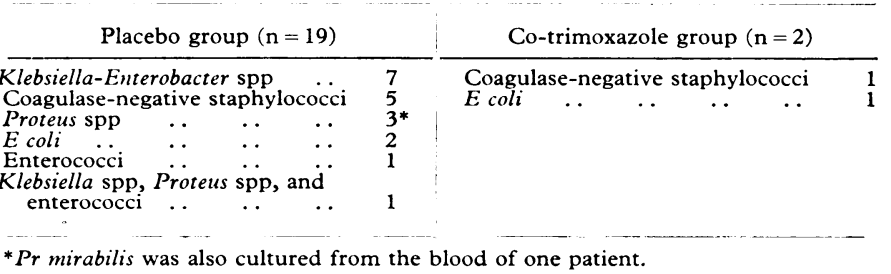

TABLE III-Organisms colonising the urethra in 51 patients

\begin{tabular}{|c|c|c|c|c|}
\hline & & & $\begin{array}{c}\text { One organism } \\
\text { isolated }\end{array}$ & $\begin{array}{c}\text { Multiple } \\
\text { organisms isolated }\end{array}$ \\
\hline \multicolumn{2}{|c|}{ Coagulase-negative staphylococci } & . & 22 & 14 \\
\hline Staph aureus .. & .. & . & 0 & 2 \\
\hline Enterococci & . & .. & 1 & $1 \overline{1}$ \\
\hline E coli $\quad \ldots$ & . & . & 1 & 3 \\
\hline Proteus spp & . & . & 0 & 6 \\
\hline $\begin{array}{l}\text { Klebsiella spp } \text { Pseudomonas aeruginosa } \\
\text { Pseudi }\end{array}$ & . & . & 0 & 2 \\
\hline Pseudomonas aeruginosa & & .. & 0 & 1 \\
\hline \multicolumn{3}{|c|}{ Total organisms } & 24 & 39 \\
\hline \multicolumn{3}{|c|}{ Total patients } & 24 & 27 \\
\hline
\end{tabular}


tured from the urine was the same as that previously shown to be colonising the urethra. No side effects were seen in the patients given placebo. Two patients treated with co-trimoxazole developed rashes after seven and eight days. These resolved after withdrawal of the drug. The mean length of postoperative stay in hospital after operation was $14.0 \pm 1.7$ days for the placebo group and $9.9 \pm 0.6$ days for the co-trimoxazole group $(\mathrm{d}=2 \cdot 269 ; \mathrm{P}<0.02)$.

\section{Discussion}

There was a highly significant reduction in the incidence of bacteriuria in those patients receiving prophylactic cotrimoxazole-both for transurethral and for retropubic operations. The criteria for diagnosing bacteriuria in this trial were exacting, with repeated urine cultures after surgery, and this may well explain the high incidence $(53 \%$ ) of bacteriuria in the placebo group. Of the organisms isolated from the patients who developed bacteriuria, Escherichia coli was cultured in only three cases, although it is the commonest urinary pathogen in both hospital and domiciliary practice. The Klebsiella-Enterobacter group and coagulase-negative staphylococci were responsible for most infections. Although the former are undoubted urinary pathogens and often resistant to antibiotics, the status of the coagulase-negative staphylococci is less easily defined, but none of the strains isolated were Micrococcus group 3, a well recognised urinary pathogen in women. Proteus spp was isolated from three patients, in one of whom the same organism was also grown from the blood and gave rise to a clinical septicaemia. Only two patients in the co-trimoxazole group developed bacteriuria: one was infected with a coagulase-negative staphylococcus in a single specimen which cleared spontaneously; the other became infected with $E$ coli. Bacteriuria develops in the patient with a catheter almost invariably, as a result of organisms ascending via the outside of the catheter, having previously colonised the urethra, ${ }^{1}$ and this was shown to be the route in the nine patients studied.

Direct comparison of our results with those in the many reported trials of prophylactic antimicrobials in prostatectomy is difficult because of variation in the study protocols. Many different antimicrobial agents have been used, including agents such as chloramphenicol that would be considered unsuitable today. Although sulphonamides have been investigated, ${ }^{--5}$ it seems that co-trimoxazole has not been evaluated. Most reported trials have included both patients already bacteriuric at the time of surgery as well as those with sterile urine, and on this basis it is hardly surprising that several workers recommend prophylactic antibiotics for patients already infected at the time of surgery. ${ }^{3}$ Antibiotics given in such circumstances are really therapeutic and not prophylactic. Recommendations for patients operated on with sterile urine are conflicting. Plorde et $a l,{ }^{6}$ for instance, found that prophylactic kanamycin given before and after surgery was "highly effective and of genuine benefit," whereas Genster and Madsen, ${ }^{3}$ in a trial of several different antimicrobials concluded they were ineffective in preventing postoperative bacteriuria. In their trial the prophylactic agent was given after operation only. Adequate blood and urine concentrations of the antimicrobial drug at the time of the operation as well as afterwards might be more effective in preventing bacteriuria than one given only afterwards.

We have shown that prophylactic co-trimoxazole dramatically reduces the incidence of bacteriuria after prostatectomy; whether such prophylaxis is justified is open to debate. Undoubtedly many patients who develop bacteriuria will not suffer adversely from it, and the bacteria may even disappear spontaneously from the urine; this seems to be particularly true for coagulase-negative staphylococci. A few patients, however, will have symptomatic bacteriuria and may even develop bacteraemia, as occurred in one of our patients receiving placebo tablets. Although resistance to co-trimoxazole did not emerge in this trial, its widespread prophylactic use might be expected to lead to an increased incidence of bacterial resistance. It is of interest that those patients receiving co-trimoxazole prophylaxis had a shorter postoperative stay in hospital than those receiving placebo. It might be argued that repeated urine cultures after surgery, enabling early detection and treatment of bacteriuria, would be a sounder approach to the problem than routine chemoprophylaxis. Nevertheless, such a system repeatedly fails through human error, and effective chemoprophylaxis is a tempting alternative.

We thank the Wellcome Foundation Limited for financial support and supplies of the placebo, and Miss C Jenkins for careful technical help.

\section{References}

${ }^{1}$ Bultitude, M I, and Eykyn, S, British fournal of Urology, 1973, 45, 678. ${ }^{2}$ Creevy, C D, and Feeney, M J, fournal of Urology, 1954, 71, 615.

${ }^{3}$ Genster, H G, and Madsen, P O, Journal of Urology, 1970, 104, 163.

${ }^{4}$ Kaplan, G W, Belman, B B, and Kropp, K A, Investigative Urology, 1969 , 7,181 .

${ }^{5} \mathrm{Herr}, \mathrm{H}$ W, fournal of Urology, 1973, 109, 686.

6 Plorde, J J, et al, New England fournal of Medicine, 1965, 272, 269.
Department of Paediatrics, St Thomas's Hospital, SE1

STEPHEN WARE, MRCP, registrar (present address: Department. of Paediatrics, St Mary's General Hospital, Milton, Portsmouth PO3 6AD) J P OSBORNE, MRCP, research registrar venously did not always prevent this. Children at risk could not be predicted on the basis of age or weight-forage. Small children should be fed as soon as practicable after operation, preferably with milk.

\section{Introduction}

Attention has been drawn to the danger of hypoglycaemia in small children at induction of anaesthesia after a long preoperative fast, ${ }^{1-4}$ but this is still not widely appreciated. The danger is usually confined to children under 4 to 5 years old who have been fasted for more than four hours, ${ }^{3}$ although low levels of glucose have been observed in several older children including two aged 12 and $15 .^{2}$ We investigated the incidence of 